\section{Kidney \\ Blood Pressure Research}

Kidney Blood Press Res 2013;38:121-131

DOI: $10.1159 / 000355758$

Published onine: Ivarch 03, 2014

(C) 2014 S. Karger AG, Basel

www.karger.com/kbr

1423-0143/14/0381-0121\$39.50/0

This is an Open Access article licensed under the terms of the Creative Commons AttributionNonCommercial 3.0 Unported license (CC BY-NC) (www.karger.com/OA-license), applicable to the online version of the article only. Distribution permitted for non-commercial purposes only.

\title{
ADAMTS-7 Expression Increases in the Early Stage of Angiotensin II-Induced Renal Injury in Elderly Mice
}

\author{
Yan-Xiang Gao ${ }^{a}$ Chang-An Yu ${ }^{b}$ Jian-Hua Luc Hong-Mei Gao ${ }^{c}$ \\ Geng Lib ${ }^{b}$ Wei Kong ${ }^{d}$ Jingang Zhenga
}

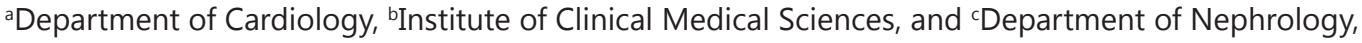
China-Japan Friendship Hospital, Chaoyang District; 'Department of Physiology and Pathophysiology, School of Basic Medical Sciences, Peking University, Key Laboratory of Molecular Cardiovascular Science, Ministry of Education, Beijing, P. R. China

\author{
Key Words \\ ADAMTS-7 • Angiotensin II • Renal injury • Early stage $・$ Inflammatory $•$ Elderly
}

\begin{abstract}
Background/Aims: We investigated the recently described family of proteinases, a disintegrin and metalloproteinase with thrombospondin motifs (ADAMTs), and matrix metalloproteinases (MMPs) as inflammatory mediators in inflammatory kidney damage by studying ADAMTS-1, -4 , and -7 and MMP-9 expression in elderly mouse kidneys after angiotensin II (Ang II) administration. Methods: Ang II $(2.5 \mu \mathrm{g} / \mathrm{kg} / \mathrm{min})$ or norepinephrine $(8.3 \mu \mathrm{g} / \mathrm{kg} / \mathrm{min})$ was subcutaneously infused in old mice. Renal injury was assessed by hematoxylin-eosin staining, 24-h albuminuria, and immunohistochemistry to evaluate inflammatory cell markers. The mRNA and protein expression of ADAMTS-1, -4 , and -7 and MMP-9 were determined using real-time PCR, Western blot, and immunohistochemistry 3 days after Ang II or norepinephrine administration. Results: Elderly mice in the Ang II group developed hypertension and pathological kidney damage. The mRNA and protein levels of ADAMTS-7 in the Ang II group were $3.3 \pm 1.1(P=0.019)$ and $1.6 \pm 0.1(P=0.047) v s .1 .0 \pm 0.1$ and $1.0 \pm 0.1$ in the control group on day 3 . In contrast, treatment with the hypertensive agent norepinephrine did not lead to obvious renal damage or an increase in renal ADAMTS-7 expression. Conclusions: Renal ADAMTS-7 expression was induced by Ang II in elderly mice. The overexpression of ADATMTS-7 might contribute to early inflammatory kidney damage associated with aging.
\end{abstract}




\section{Kidney Blood Pressure Research}

Kidney Blood Press Res 2013;38:121-131

\begin{tabular}{l|l}
\hline DOI: $10.1159 / 000355758$ & C 2014 S. Karger AG, Basel
\end{tabular}

Published onIIne: IVarch 03, 2014

www.karger.com/kbr

Gao/Yu/Lu/Gao/Li/Kong/Zheng: ADAMTS-7 Expression Increases in Ang II-Induced Renal Injury

\section{Introduction}

Kidney disease has emerged as a worldwide health problem. The incidence of chronic kidney disease (CKD) and end-stage renal disease (ESRD) in the general population has increased enormously over the past several decades, becoming a significant burden for healthcare systems. To adequately address this issue, detecting kidney disease patients early and optimizing their treatment are crucial.

In most species, aging is associated with impaired adaptive and homeostatic mechanisms, leading to susceptibility to environmental or internal stressors with increasing rates of disease [1, 2]. Age-related changes lead to a functional decline of several organs, including the kidneys [3]. Clinical studies have shown that the development of CKD is associated with the aging process $[4,5]$. Even adjustments for age-associated diseases do not explain the higher rate of morbidity observed in elderly patients [6]. The underlying mechanism that might explain this phenomenon remains unclear.

The renin-angiotensin system, especially angiotensin II (Ang II), plays a key role in the progression of chronic kidney damage, contributing to renal inflammation and fibrosis [79]. Ang II can both directly and indirectly activate different signaling pathways to trigger the inflammatory response in kidney disease [7, 10,11]. Many in vitro and experimental studies have demonstrated that Ang II activates renal cells to produce inflammatory mediators.

A growing body of evidence suggests that inflammation plays a role in the development of CKD [5]. Increased interest in inflammation has led to the investigation of various inflammatory mediators, including extracellular matrix (ECM)-degrading proteinases. The most commonly studied ECM-degrading proteinase in kidney disease is matrix metalloproteinase-9 (MMP-9), which has been shown to contribute to the pathogenesis of renal fibrosis via osteopontin cleavage [12].

The recently identified metalloproteinase family of a disintegrin and metalloproteinase with thrombospondin motifs (ADAMTS) also degrades the ECM. ADAMTS have been implicated in the development and progression of many cardiovascular diseases and inflammation. ADAMTS-1 might facilitate atherogenesis by cleaving the ECM protein versican [13]. ADAMTS-4 was identified as an inflammatory-regulated enzyme in macrophage-rich areas of human atherosclerotic plaques [14]. ADAMTS-7 was shown to facilitate vascular smooth muscle cell migration, thereby promoting neointima formation following vascular injury [15].

For these reasons, the purpose of the present study was to investigate whether ADAMTS is involved in the early phase of inflammatory renal injury induced by Ang II in elderly mice. Our results might contribute to the early diagnosis and treatment of kidney disease.

\section{Materials and Methods}

\section{Ethics statement}

This study was performed in strict accordance with the recommendations of the Guide for the Care and Use of Laboratory Animals of the National Institutes of Health. The protocol was approved by the Committee on the Ethics of Animal Experiments of China-Japan Friendship Hospital. All of the surgeries were performed in sodium pentobarbital-anesthetized mice, and all efforts were made to minimize suffering. Thirty-sixweek-old male C57BL/6 mice were purchased from the Animal Center of Peking University Health Science Center (Beijing, China) and maintained in a specific pathogen-free facility at the Experimental Center of China-Japan Friendship Hospital (accredited for animal care by the Chinese Association for Accreditation of Laboratory Animal Care) under a $12 \mathrm{~h} / 12 \mathrm{~h}$ light/dark cycle with controlled room temperature and free access to standard chow and tap water.

\section{Animal experiments}

Two/three groups of mice ( $n=6$ per group) received continuous Ang II $(2.5 \mu \mathrm{g} / \mathrm{kg} / \mathrm{min}$; Sigma Chemical, St Louis, MO, USA) [16], norepinephrine ( $8.3 \mu \mathrm{g} / \mathrm{kg} / \mathrm{min}$; Sigma Chemical, St Louis, MO, USA) [17], or saline via subcutaneous osmotic minipumps (Alza, Palo Alto, CA, USA) for 3 days. The mice in each 


\section{Kidney \\ Blood Pressure Research}

Kidney Blood Press Res 2013;38:121-131

\begin{tabular}{l|l}
\hline DOI: $10.1159 / 000355758$ & (C) 2014 S. Karger AG, Basel
\end{tabular}

Published online: IVarch 03, 2014

www.karger.com/kbr

Gao/Yu/Lu/Gao/Li/Kong/Zheng: ADAMTS-7 Expression Increases in Ang II-Induced Renal Injury

group underwent renal biopsy under anesthesia on day 3 and were then sacrificed by sodium pentobarbital overdose.

\section{Cell culture}

Human embryonic kidney 293 (HEK293) cells (ATCC CRL-1573 line) were grown in Dulbecco's Modified Eagle Medium with 10\% fetal bovine serum, $2 \mathrm{mmol} / \mathrm{L}$ glutamine, $100 \mathrm{U} / \mathrm{mL}$ penicillin, and 100 $\mathrm{mg} / \mathrm{mL}$ streptomycin in $5 \% \mathrm{CO}_{2}$ at $37^{\circ} \mathrm{C}$. For treatment, HEK2 93 cells were cultured at $40-50 \%$ of confluence and then incubated for $24 \mathrm{~h}$ with different doses of Ang II or $1 \mu \mathrm{M}$ Ang II for different times.

\section{Blood pressure measurement}

Arterial systolic blood pressure (SBP), diastolic blood pressure (DBP), mean blood pressure (MBP), and heart rate (HR) were measured in conscious, restrained mice using a noninvasive computerized tail-cuff system (Muromachi Kikai, Tokyo, Japan). Measurements were performed every day, beginning 2 days before the placement of the minipumps. The blood pressure value for each mouse was calculated as the average of three separate measurements in each session.

\section{Urine albumin measurement}

To measure 24-h proteinuria, the mice were placed in individual mouse metabolic cages with free access to food and water. Urinary albumin excretion was assayed using a mouse albumin enzyme-linked immunosorbent assay quantification kit (Bethyl Laboratories, Montgomery, TX, USA).

\section{Histology and immunohistochemistry}

Paraformaldehyde-fixed tissue was embedded with optimum cutting temperature compound or paraffin and processed, and $5 \mu \mathrm{m}$ sections were stained with hematoxylin-eosin. Additional sections were immunostained using an indirect horseradish peroxidase immunoperoxidase method using specific antibodies for the following antigens: ADAMTS-7 (ImmunoWay, Newark, DE, USA) and CD68 and neutrophil elastase (Santa Cruz Biotechnology, Santa Cruz, CA, USA). Negative controls for the immunostaining consisted of replacing each of the primary antibodies with an equivalent concentration of irrelevant rabbit polyclonal antibody. At least three different specimens were analyzed. The area of positive staining or tubular lumen diameter was analyzed using ImagePro-Plus 6.0 software (Media Cybernetics, Singapore, Singapore). For each kidney, six randomly selected fields were analyzed in a blinded manner by a technician who had no knowledge of the specific background of the study.

\section{Quantitative real-time RT-PCR}

Total RNA from kidney or HEK293 cells was isolated using Trizol reagent (Applygen Technologies, Beijing, China) and reverse-transcribed with a reverse transcription system (Promega, Madison, WI, USA). The reaction mixture then underwent PCR. The amount of PCR products formed in each cycle was evaluated by SYBR Green I fluorescence. Amplification reactions were performed using the ABI Prism 7500 PCR System. All of the amplification reactions underwent 35 cycles and were performed in duplicate (an initial stage of $5 \mathrm{~min}$ at $95^{\circ} \mathrm{C}$, followed by a three-step cycle of $30 \mathrm{~s}$ at $95^{\circ} \mathrm{C}, 30 \mathrm{~s}$ at $60^{\circ} \mathrm{C}$, and $30 \mathrm{~s}$ at $72^{\circ} \mathrm{C}$ ). The accuracy of the PCR products was confirmed by sequencing the amplicons. The relative target mRNA levels were normalized to the internal control, $\beta$-actin. The following primers were used: ADAMTS-1 (forward, TTTGGCCAGCAGCTACATCT; reverse, CACACCTTCACAGAGGCTGA), ADAMTS-4 (forward, GCCTTCCTCCTGTCCTTAGC; reverse, TAGCAACATCTCCCCAAAGG), ADAMTS-7 (forward, AACCAGGAACGCCTACCTTT; reverse, CGGGGTCCTTGCTACTGTTA), MMP-9 (forward, CCAGATATGGGAGAGAAGC; reverse, GGCCTTTGAAGGTTTGGAAT), $\beta$-actin(forward,ATCTGGCACCACACCTTC; reverse, AGCCAGGTCCAGACGCA).

\section{Western blot}

The extracts of mouse tissue or HEK293 cells were collected using tissue/cell lysis buffer (Beyotime, Jiangsu, China) plus $1 \mathrm{mM}$ phenylmethylsulfonyl fluoride. Total protein was quantified using a bicinchoninic acid protein assay (Pierce, Rockford, IL, USA). Proteins were separated by $10 \%$ sodium dodecyl sulfatepolyacrylamide gel electrophoresis (SDS-PAGE) and electrophoretically transferred onto nitrocellulose membranes, which were incubated with an anti- $\beta$-actin antibody (MBL, Nagoya, Japan) or anti-ADAMTS-1, ADAMTS-4, ADAMTS-7, or MMP-9 antibody (Abcam, Cambridge, MA, USA), washed, and incubated 


\section{Kidney Blood Pressure Research}

Kidney Blood Press Res 2013;38:121-131

\begin{tabular}{l|l}
\hline DOI: $10.1159 / 000355758$ & $\begin{array}{l}\text { C 2014 S. Karger AG, Basel } \\
\text { www.karger.com/kbr }\end{array}$ \\
\hline
\end{tabular}

Gao/Yu/Lu/Gao/Li/Kong/Zheng: ADAMTS-7 Expression Increases in Ang II-Induced Renal Injury

with an appropriate IRDye800-conjugated second antibody (Rockland, Gilbertsville, PA, USA). Specific immunofluorescence bands were detected using the Odyssey infrared imaging system (LI-COR Biosciences, Lincoln, NE, USA).

\section{Statistical analysis}

All of the results are expressed as the mean \pm SEM or original data that represented one of at least three independent experiments. The data were analyzed using an unpaired Student's $t$-test and two-way analysis of variance (ANOVA) with Prism software (GraphPad, La Jolla, CA, USA) followed by the StudentNewman-Keuls post hoc test. $P<0.05$ was considered statistically significant.

\section{Results}

Ang II-induced blood pressure elevations and renal injury

Blood pressure in the control and Ang II mice were in the normotensive range before Ang II administration (Fig. 1a-c). After placement of the subcutaneous osmotic minipumps that delivered Ang II (2.5 $\mu \mathrm{g} / \mathrm{kg} / \mathrm{min})$ [16], hypertension developed in the old mice. The SBP, DBP, and MBP in Ang II-infused mice were significantly higher after Ang II administration, whereas blood pressure in vehicle-infused mice remained normal during the study (Fig. 1ac). Mean SBP in the control and Ang II mice was $108 \pm 5 \mathrm{mmHg} v s .141 \pm 5 \mathrm{mmHg}(P<0.001)$ on day 3 (Fig. 1a). No difference in HR was detected between Ang II-infused and control mice (Fig. 1d).

The renal histopathological findings are shown in Fig. 1e-i. Marked tubular injury, consisting of both tubular atrophy and tubular dilatation in the renal cortex and medulla, was found in Ang II-infused mice; none of the control mice had evidence of tubular injury on day 3. In contrast, Ang II exerted no marked effect on glomerular volume or cellularity.

Tubular injury in Ang II-infused mice was associated with inflammatory cell infiltration and significant albuminuria. Twenty-four-hour albuminuria in the control and Ang II mice was $163 \pm 40 \mu \mathrm{g} v s .487 \pm 94 \mu \mathrm{g}(P<0.01)$ on day 3 (Fig. 4o). Immunohistochemical staining was performed based on neutrophil elastase and CD68 expression, markers of neutrophils and macrophages, respectively. Both neutrophil elastase-positive cells and CD68-positive cells were found in renal tissue in Ang II-infused mice (Fig. 4h-m).

\section{Renal ADAMTS-7 mRNA and protein expression in Ang II-infused mice}

Elevated mRNA and protein expression of ADAMTS-7 was observed in the kidneys in Ang II-infused mice (Fig. 2c, 3a). The mRNA and protein levels of ADAMTS-7 were much higher in Ang II-infused mice compared with the control group (3.3 \pm 1.1 vs. $1.0 \pm 0.1, p=$ 0.019 , and $1.6 \pm 0.1$ vs. $1.0 \pm 0.1, p=0.047$; Fig. 2c, 3d) on day 3 after Ang II administration. No differences in the mRNA and protein expression of ADAMTS-1, ADAMTS-4, and MMP9 were detected in the kidneys in the two groups (Fig. 2a, b, d, 3a-c, e). Additionally, immunohistochemistry indicated an increase in ADAMTS-7 expression in the kidneys in Ang II-infused mice compared with controls on day 3 (Fig. 3f-h).

\section{Norepinephrine-induced blood pressure elevations and renal injury}

To investigate whether Ang II-induced renal injury was attributable simply to elevated blood pressure, we used norepinephrine, which acts through hypertensive mechanisms that are distinct from Ang II [18]. Norepinephrine infusion $(8.3 \mu \mathrm{g} / \mathrm{kg} / \mathrm{min})$ over a 3-day period induced blood pressure elevations that were comparable to Ang II infusion in elderly

Fig. 1. Angiotensin II (Ang II)-induced renal injury in elderly mice on day 3. a-d Arterial systolic blood pressures (SBP), diastolic blood pressure (DBP), mean blood pressure (MBP), and heart rate (HR). Representative micrographs of the renal cortex $(\mathrm{e}, \mathrm{g})$ and medulla $(\mathrm{f}, \mathrm{h})$ subjected to hematoxylin-eosin (HE) staining and quantification of tubular lumen diameter (i) (200× magnification). The data are expressed as mean \pm SEM. ${ }^{*} P<0.05,{ }^{* * *} P<0.001, v s$. controls $(n=6)$. 


\section{Kidney \\ Blood Pressure Research}

Kidney Blood Press Res 2013;38:121-131

DOI: $10.1159 / 000355758$

Publisned onIIne: IVarch 03, 2014

C 2014 S. Karger AG, Basel

www.karger.com/kbr

125

Gao/Yu/Lu/Gao/Li/Kong/Zheng: ADAMTS-7 Expression Increases in Ang II-Induced Renal Injury $\mathbf{a}$

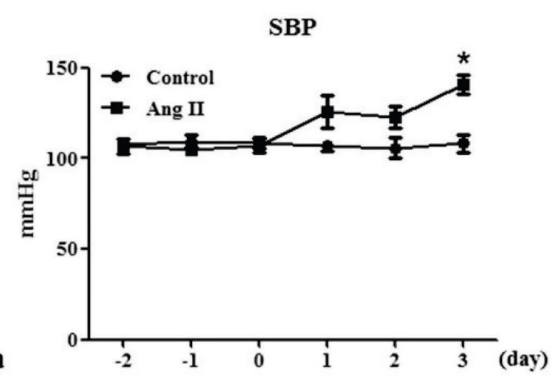

c
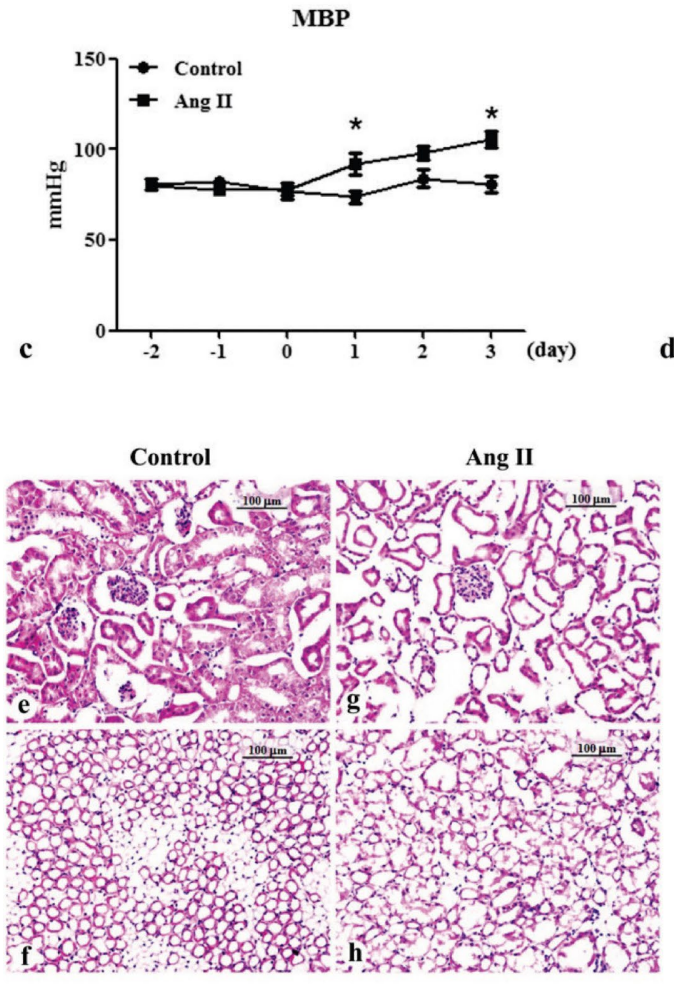

DBP

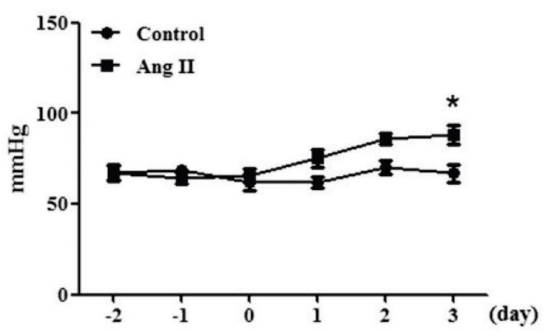

HR

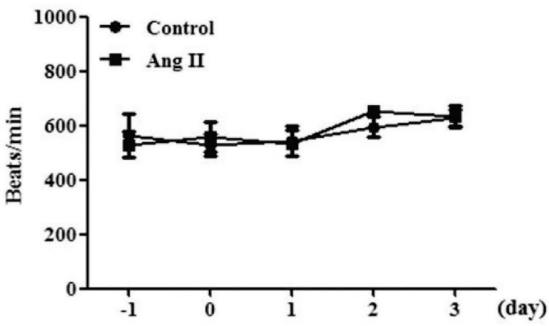

Fig. 2. ADAMTS-7 mRNA expression was increased by Ang II infusion in elderly mice on day 3 . a-d mRNA levels of ADAMTS-1, A D A M T S - 4 , ADAMTS-7, and MMP-9 measured by quantitative PCR. The data are expressed as mean \pm SEM. $* P<$ $0.05(n=6)$.

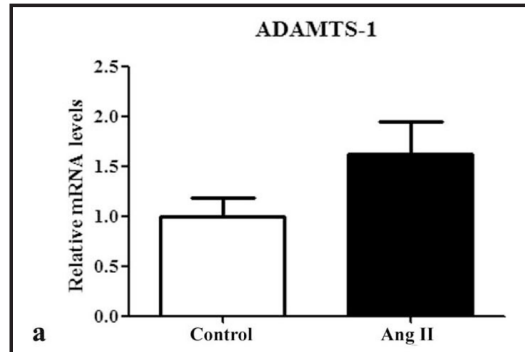

ADAMTS-7

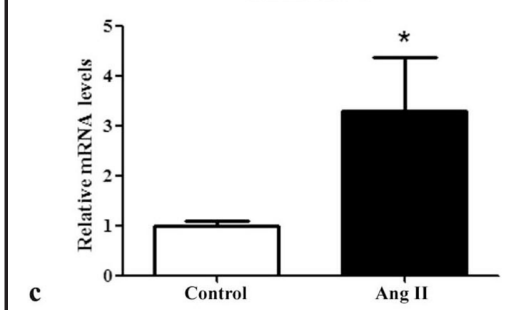

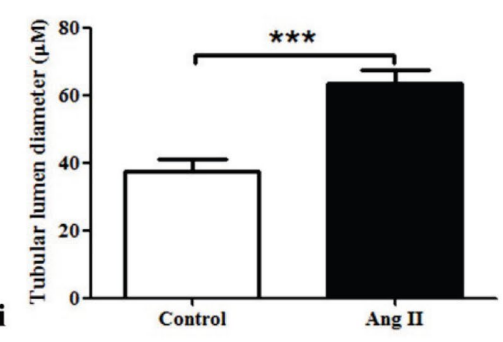

b

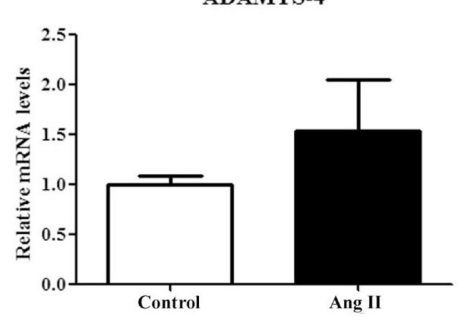

MMP-9

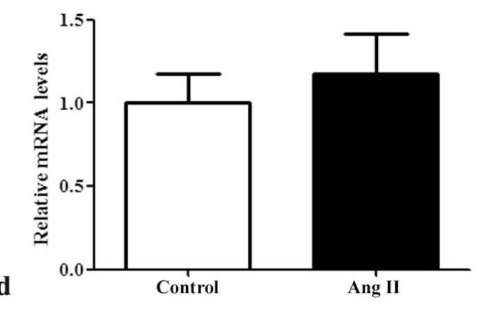




\section{Kidney Blood Pressure Research}

Fig.

A D A M T S - 7 protein expression was increased by Ang II infusion in elderly mice on day 3. a-e Representative Western blots of ADAMTS-1, A D A M T S - 4, ADAMTS-7, and MMP-9 protein expression and quantificati on. f-h Representative immunohistochemical staining of ADAMTS-7 ex pres s i o n and quantification (200x magnification). The data are expressed as mean \pm SEM. ${ }^{*} P$ $<0.05(n=6)$.
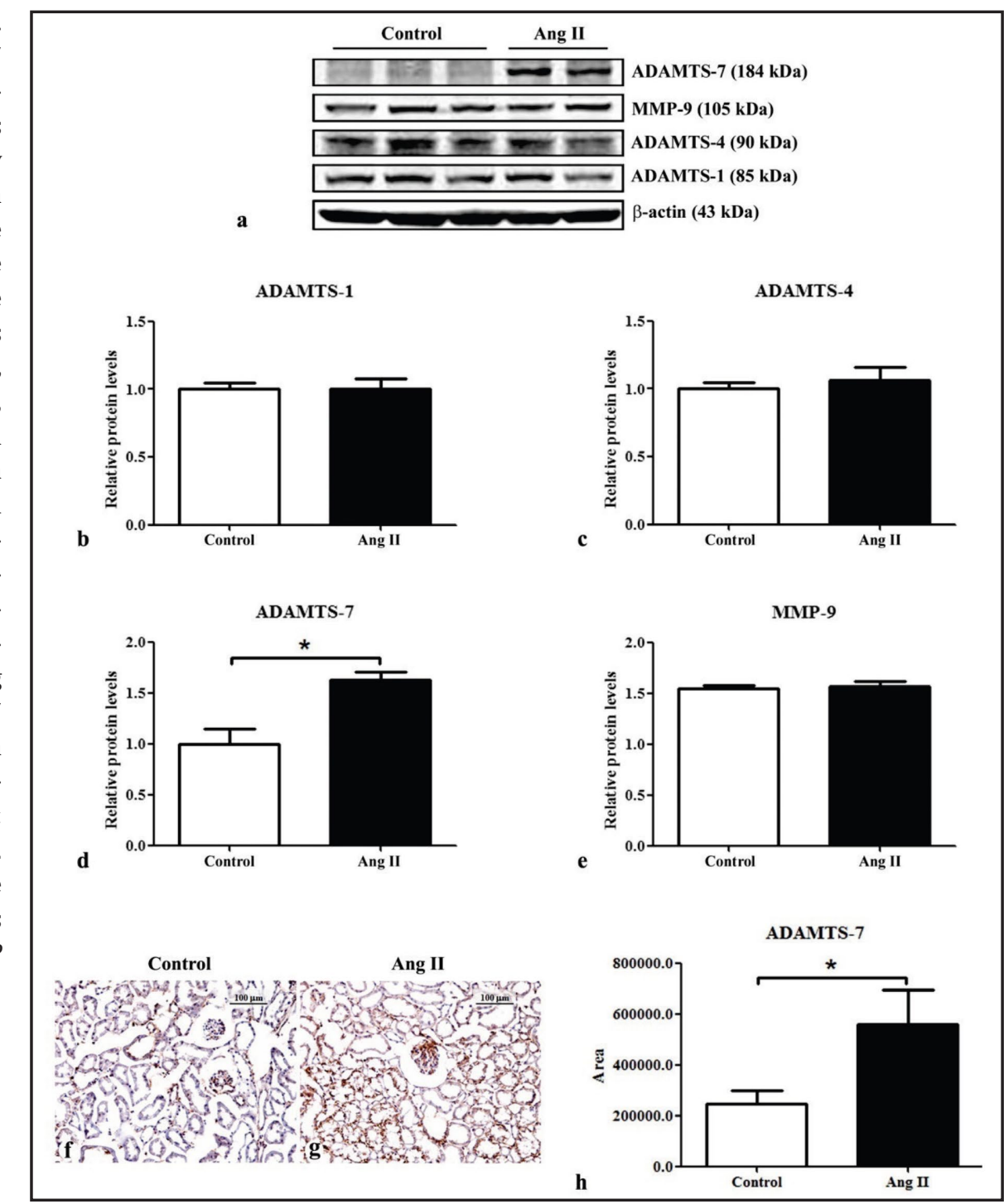

mice on days 1-3 (Fig. 4a-c) [17]. A certain degree of tubular atrophy and tubular dilatation was found in the renal cortex in norepinephrine-infused mice (Fig. 4e-g, n), but none of the norepinephrine mice exhibited evidence of albuminuria or neutrophil elastase- or CD68positive cell infiltration (Fig. 4h-m, o).

Renal ADAMTS-7 mRNA and protein expression in norepinephrine-infused mice

To investigate the mechanism of the increase in ADAMTS-7 expression, we detected ADAMTS-7 expression in the kidneys in norepinephrine-infused mice. The mRNA and protein expression of ADAMTS-7 did not obviously change in the kidneys in norepinephrine-infused mice (Fig. 5a-c). Additionally, immunohistochemical studies indicated similar ADAMTS-7 expression in the kidneys in norepinephrine-infused mice compared with controls on day 3 (Fig. 5d-g). Thus, we conclude that Ang II itself and not hypertension was involved in renal injury and the increase in ADAMTS-7 expression in the early stage of renal injury.

\section{ADAMTS-7 mRNA and protein expression in Ang II-stimulated HEK293 cells}

To further investigate the effect of Ang II on ADAMTS-7 expression, we examined ADAMTS-7 expression in HEK293 cells incubated with different doses of Ang II for $24 \mathrm{~h}$ or $1 \mu \mathrm{M}$ Ang II for different times. Compared with controls, ADAMTS-7 mRNA and protein expression was concentration- and time-dependently upregulated by Ang II (Fig. 6a-d). The 


\section{Kidney \\ Blood Pressure Research}

Kidney Blood Press Res 2013;38:121-131

DOI: 10.1159/000355758

Published onIIne: IVlarch 03, 2014

(C) 2014 S. Karger AG, Basel

www.karger.com/kbr

127

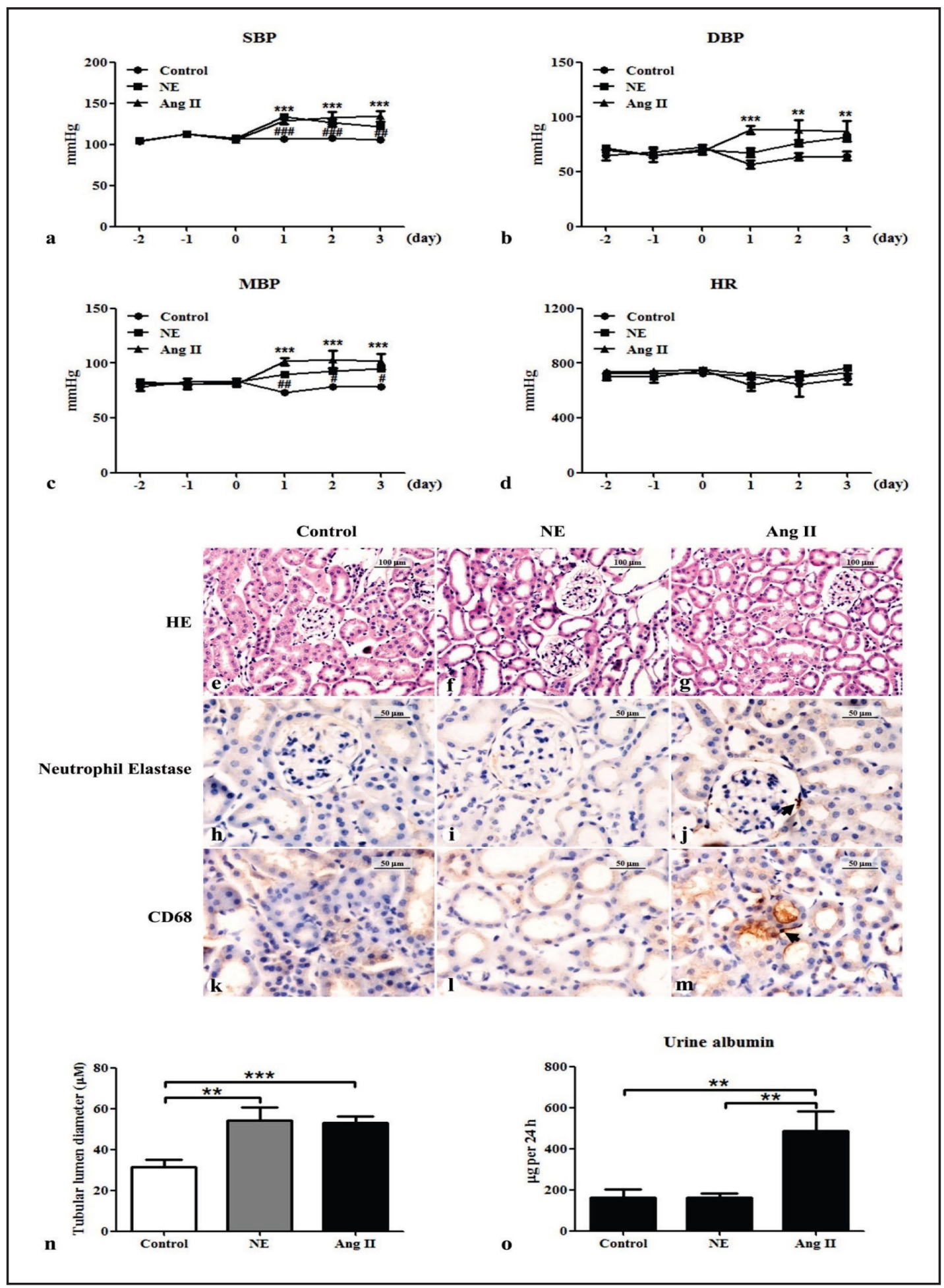

Fig. 4. Renal injury in elderly mice was induced by Ang II but not norepinephrine (NE) on day 3. a-d SBP, DBP, MBP, and HR. The figure shows representative micrographs of renal tissue subjected to HE staining (eg) and quantification of tubular lumen diameter (n). h-m Representative immunohistochemical staining of neutrophil elastase or CD68 expression (400× magnification). The arrows indicate neutrophil elastase- or CD68-positive cells. o Twenty-four-hour proteinuria. The data are expressed as mean \pm SEM. ${ }^{*} P<0.05$, ${ }^{* *} P$ $<0.01,{ }^{* * *} P<0.001, v s$. controls; ${ }^{\#} P<0.05$, ${ }^{\# \#} P<0.01,{ }^{\# \# \#} P<0.001, v s$. controls $(n=6)$. 


\section{Kidney \\ Blood Pressure \\ Research}

Kidney Blood Press Res 2013;38:121-131

DOI: $10.1159 / 000355758$

Published online: IVarch 03, 2014

(c) 2014 S. Karger AG, Basel

www.karger.com/kbr

128

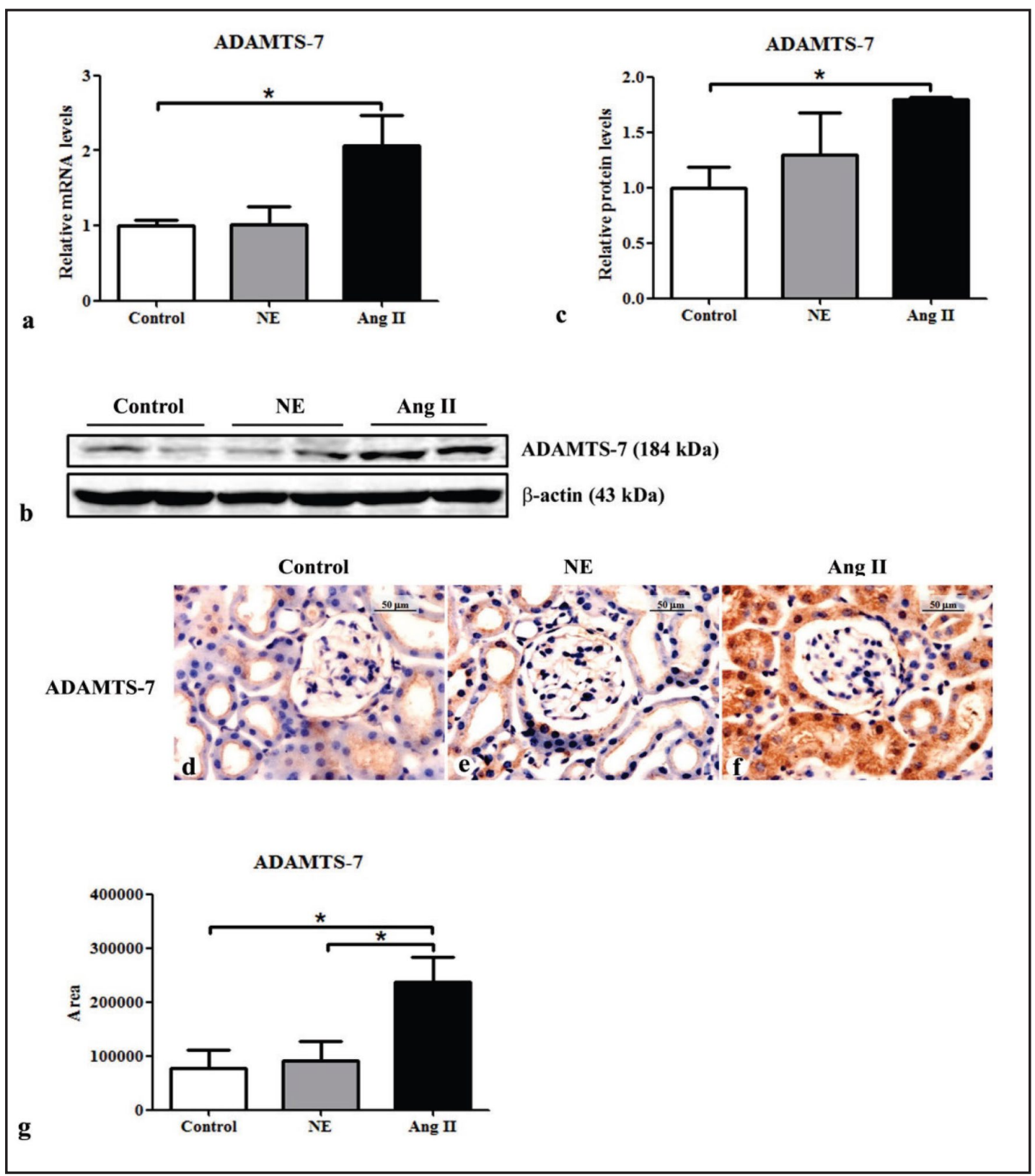

Fig. 5. ADAMTS-7 expression in the kidneys in elderly mice is regulated by Ang II but not NE on day 3. a mRNA levels of ADAMTS-7 measured by quantitative PCR. b, c Representative Western blot of ADAMTS-7 protein expression and quantification. $\mathrm{d}$-g Representative immunohistochemical staining of ADAMTS-7 expression and quantification (400× magnification). The data are expressed as mean \pm SEM. $* P<0.05(n=6)$.

protein levels of ADAMTS-7 were much higher in Ang II-stimulated cells compared with controls ( $1.5 \pm 0.1$ vs. $1.0 \pm 0.01, P=0.047$; Fig. 6f) $24 \mathrm{~h}$ after $1 \mu \mathrm{M}$ Ang II incubation.

\section{Discussion}

Despite the technical advances in and resources dedicated to the treatment of CKD, it is a growing problem worldwide, especially in the aging population. Clarification of kidney disease mechanisms and the early detection of kidney damage are clearly needed. 


\section{Kidney Blood Pressure Research}

Kidney Blood Press Res 2013;38:121-131

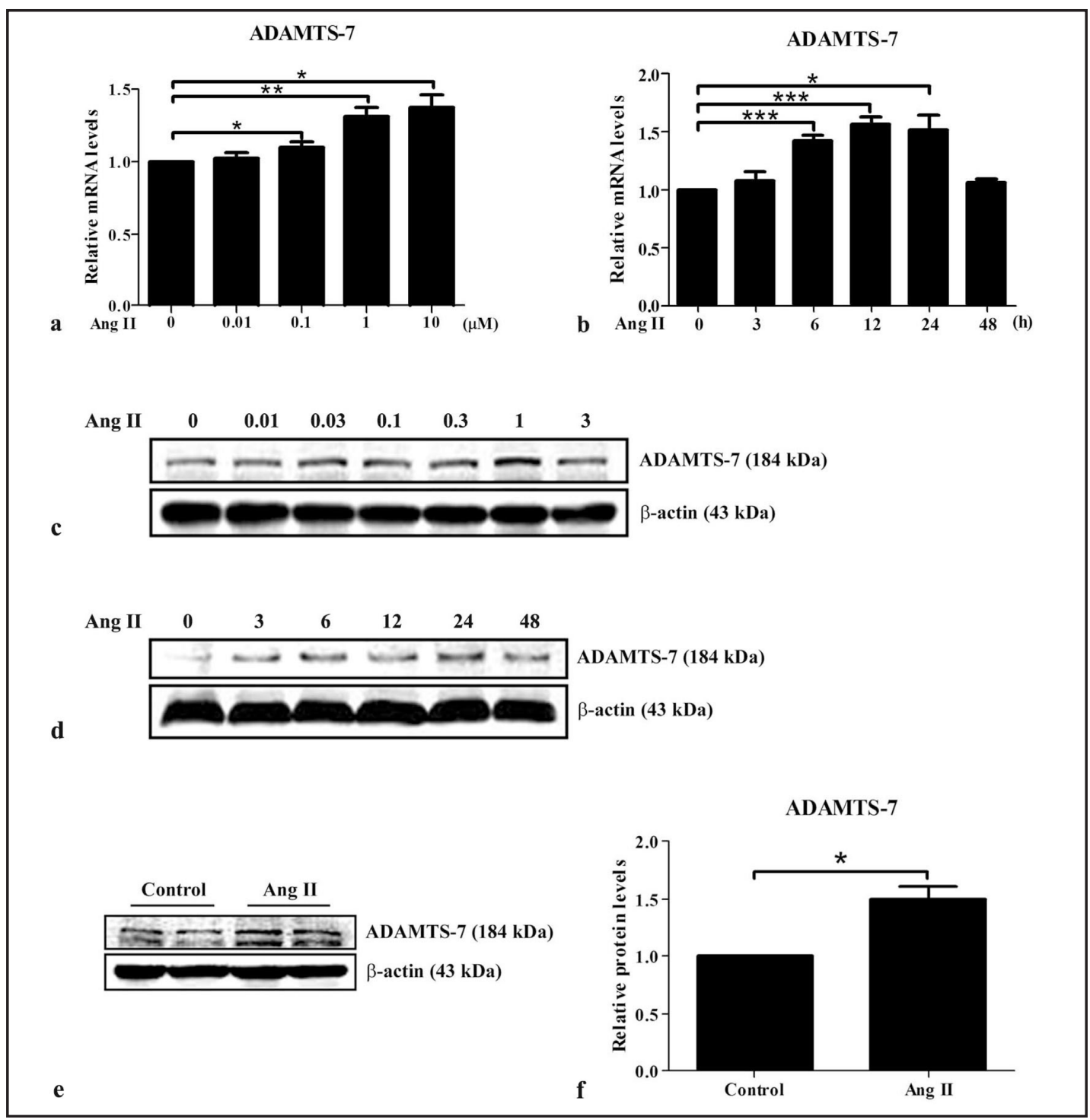

Fig. 6. Ang II concentration- and time-dependently promoted ADAMTS-7 expression in HEK293 cells. a, b mRNA levels of ADAMTS-7 measured by quantitative PCR. c, d Representative Western blot of ADAMTS-7 protein expression and quantification. The data are expressed as mean \pm SEM. ${ }^{*} P<0.05,{ }^{* *} P<0.01,{ }^{* * *} P<$ $0.001(n=3)$.

Hypertension is one of the most important causes of CKD. In the present study, Ang II induced modest hypertension and evident renal injury, including tubular atrophy, tubular dilatation, inflammatory cell infiltration, and albuminuria, in elderly mice in the early stage. To some extent, our results perhaps explain why sustained hypertension may develop several weeks to months after a short series of daily Ang II infusions [19] because kidney damage can exacerbate the development of hypertension.

Matrix metalloproteinases are candidates in the pathological molecular mechanisms of CKD. These enzymes degrade the ECM, modulate inflammation, and regulate tissue remodeling. One study demonstrated that MMP-9 was elevated in the pathogenesis of renal fibrosis [12], and MMP-2 and MMP-10 were elevated in ESRD [20]. Cheng et al. demonstrated that MMP-2 overexpression in transgenic mice leads to structural alterations in the tubular basement membrane, triggering the tubular epithelial-mesenchymal transition and resulting in tubular atrophy, fibrosis, and renal failure [21]. 


\section{Kidney \\ Blood Pressure Research}

Kidney Blood Press Res 2013;38:121-131

\begin{tabular}{l|l}
\hline DOI: $10.1159 / 000355758$ & C 2014 S. Karger AG, Basel
\end{tabular}

Published onlıne: VIarch 03, 2014

www.karger.com/kbr

Renal Injury

ADAMTS is a recently identified family of extracellular metalloproteinases that has been shown to participate in tissue destruction [22]. The ADAMTS family of proteins comprises 20 members. ADAMTS-1, ADAMTS-4, and ADAMTS-7 are particularly well-studied members of this family $[23,24]$. Accumulating studies have shown that ADAMT-7 plays an important role in cardiovascular disease [25]. Our previous studies also showed that ADAMTS-7 mediated injury-induced vascular remodeling and calcification $[15,26]$. The role of ADAMTS-7 in inflammatory renal injury has not yet been studied. In the present study, we found that renal ADAMTS-7 expression was induced in old mouse kidneys on day 3 after Ang II administration, with no difference in MMP-9, ADAMTS-1, and ADAMTS-4 expression between the two groups.

To exclude the possibility that Ang II-induced renal injury and ADAMTS-7 expression might be simply attributable to increased blood pressure, we compared the effects of norepinephrine and Ang II infusion on renal function and renal ADAMTS-7 expression. Norepinephrine infusion caused blood pressure elevations, tubular atrophy, and tubular dilatation that were comparable to Ang II infusion in elderly mice on day 3, but only Ang II-infused mice had evidence of albuminuria, inflammatory cell infiltration, and increased ADAMTS-7 expression (Fig. 4, 5).

We also histologically analyzed ADAMTS-1, -4 , and -7 and MMP-9 expression in the kidneys in 20-week-old male C57BL/6 mice with Ang II-mediated kidney damage (data not shown). Adult mice in the Ang II group developed more severe hypertension. However, the histological examination identified fewer renal histopathological changes in adult mice than in elderly mice. No significant differences in the mRNA and protein levels of ADAMTS-1, -4, and -7 and MMP9 were detected between the two groups of adult mice. This may indicate that the aging kidney is more sensitive to inflammation, which may be because of differential ADAMTS-7 induction between adult and aging mice.

\section{Conclusion}

In summary, we found renal injury and increased renal ADAMTS-7 expression in the early stage of Ang II-mediated inflammatory kidney impairment in old mice. ADAMTS-7 may play important pathogenic roles in the progression of elderly kidney damage.

\section{Acknowledgements}

This work was supported by the National Natural Science Foundation of China (URL: www.nsfc.gov.cn/Portal0/default152.htm) [81170287 and 30770865 to J. Zheng]. The funding agency had no role in the study design, data collection and analysis, decision to publish, or preparation of the manuscript.

\section{References}

1 Campbell KH, O'Hare AM: Kidney disease in the elderly: update on recent literature. Curr Opin Nephrol Hypertens 2008;17:298-303.

2 O'Hare AM, Bertenthal D, Covinsky KE, Landefeld CS, Sen S, Mehta K, Steinman MA, Borzecki A, Walter LC: Mortality risk stratification in chronic kidney disease: one size for all ages? J Am Soc Nephrol 2006;17:846853.

3 Davies I, Fotheringham AP, Faragher BE: Age-associated changes in the kidney of the laboratory mouse. Age Ageing 1989;18:127-133.

4 Klag MJ, Whelton PK, Randall BL, Neaton JD, Brancati FL, Ford CE, Shulman NB, Stamler J: Blood pressure and end-stage renal disease in men. N Engl J Med 1996;334:13-18.

5 Izquierdo MC, Perez-Gomez MV, Sanchez-Nino MD, Sanz AB, Ruiz-Andres O, Poveda J, Moreno JA, Egido J, Ortiz A: Klotho, phosphate and inflammation/ageing in chronic kidney disease. Nephrol Dial Transplant 2012;27 Suppl 4:iv6-10. 


\section{Kidney \\ Blood Pressure Research}

\begin{tabular}{|c|c|}
\hline Kidney Blood Press Res 20 & \\
\hline $\begin{array}{l}\text { DOI: } 10.1159 / 000355758 \\
\text { Published online: IVarch 03, } 2014\end{array}$ & $\begin{array}{l}\text { (c) } 2014 \text { S. Karger AG, Basel } \\
\text { www.karger.com/kbr }\end{array}$ \\
\hline
\end{tabular}

Gao/Yu/Lu/Gao/Li/Kong/Zheng: ADAMTS-7 Expression Increases in Ang II-Induced Renal Injury

6xcerpts from United States Renal Data System 1999 Annual Data Report. Am J Kidney Dis 1999;34:S1176.

7 Ruiz-Ortega M, Ruperez M, Esteban V, Rodriguez-Vita J, Sanchez-Lopez E, Carvajal G, Egido J: Angiotensin II: a key factor in the inflammatory and fibrotic response in kidney diseases. Nephrol Dial Transplant 2006;21:16-20.

8 Lavoz C, Rodrigues-Diez R, Benito-Martin A, Rayego-Mateos S, Rodrigues-Diez RR, Alique M, Ortiz A, Mezzano S, Egido J, Ruiz-Ortega M: Angiotensin II contributes to renal fibrosis independently of Notch pathway activation. PLoS One 2012;7:e40490.

-9 Solini A, Rossi C, Santini E, Madec S, Salvati A, Ferrannini E: Angiotensin-II and rosuvastatin influence matrix remodeling in human mesangial cells via metalloproteinase modulation. J Hypertens 2011;29:19301939.

10 Whiting C, Castillo A, Haque MZ, Majid DS: Protective role of the endothelial isoform of nitric oxide synthase in ANG II-induced inflammatory responses in the kidney. Am J Physiol Renal Physiol 2013;305:F1031-F1041.

11 Wolf G: Renal injury due to renin-angiotensin-aldosterone system activation of the transforming growth factor-beta pathway. Kidney Int 2006;70:1914-1919.

12 Tao H, Rui C, Zheng J, Tang J, Wu L, Shi A, Chen N, He R, Wu C, Li J, Yin X, Zhang P, Zhu Z, Tao J, Xiao J, Mao $\mathrm{C}, \mathrm{Xu} \mathrm{Z}$ : Angiotensin II-mediated vascular changes in aged offspring rats exposed to perinatal nicotine. Peptides 2013;44:111-119.

-13 Jonsson-Rylander AC, Nilsson T, Fritsche-Danielson R, Hammarstrom A, Behrendt M, Andersson JO, Lindgren K, Andersson AK, Wallbrandt P, Rosengren B, Brodin P, Thelin A, Westin A, Hurt-Camejo E, LeeSogaard CH: Role of ADAMTS-1 in atherosclerosis: remodeling of carotid artery, immunohistochemistry, and proteolysis of versican. Arterioscler Thromb Vasc Biol 2005;25:180-185.

14 Wagsater D, Bjork H, Zhu C, Bjorkegren J, Valen G, Hamsten A, Eriksson P: ADAMTS-4 and -8 are inflammatory regulated enzymes expressed in macrophage-rich areas of human atherosclerotic plaques. Atherosclerosis 2008;196:514-522.

15 Wang L, Zheng J, Bai X, Liu B, Liu CJ, Xu Q, Zhu Y, Wang N, Kong W, Wang X: ADAMTS-7 mediates vascular smooth muscle cell migration and neointima formation in balloon-injured rat arteries. Circ Res 2009;104:688-698.

16 Tieu BC, Lee C, Sun H, Lejeune W, Recinos A, 3rd, Ju X, Spratt H, Guo DC, Milewicz D, Tilton RG, Brasier AR: An adventitial IL-6/MCP1 amplification loop accelerates macrophage-mediated vascular inflammation leading to aortic dissection in mice. J Clin Invest 2009;119:3637-3651.

17 Gavazzi G, Deffert C, Trocme C, Schappi M, Herrmann FR, Krause KH: NOX1 deficiency protects from aortic dissection in response to angiotensin II. Hypertension 2007;50:189-196.

18 Rajagopalan S, Kurz S, Munzel T, Tarpey M, Freeman BA, Griendling KK, Harrison DG: Angiotensin IImediated hypertension in the rat increases vascular superoxide production via membrane NADH/NADPH oxidase activation. Contribution to alterations of vasomotor tone. J Clin Invest 1996;97:1916-1923.

19 Koletsky S, Rivera-Velez JM, Pritchard WH: Production of hypertension and vascular disease by angiotensin. Arch Pathol 1966;82:99-106.

20 Friese RS, Rao F, Khandrika S, Thomas B, Ziegler MG, Schmid-Schonbein GW, O'Connor DT: Matrix metalloproteinases: discrete elevations in essential hypertension and hypertensive end-stage renal disease. Clin Exp Hypertens 2009;31:521-533.

21 Cheng S, Pollock AS, Mahimkar R, Olson JL, Lovett DH: Matrix metalloproteinase 2 and basement membrane integrity: a unifying mechanism for progressive renal injury. FASEB J 2006;20:1898-1900.

-22 Kuno K, Kanada N, Nakashima E, Fujiki F, Ichimura F, Matsushima K: Molecular cloning of a gene encoding a new type of metalloproteinase-disintegrin family protein with thrombospondin motifs as an inflammation associated gene. J Biol Chem 1997;272:556-562.

23 Salter RC, Ashlin TG, Kwan AP, Ramji DP: ADAMTS proteases: key roles in atherosclerosis? J Mol Med (Berl) 2010;88:1203-1211.

24 Pu X, Xiao Q Kiechl S, Chan K, Ng FL, Gor S, Poston RN, Fang C, Patel A, Senver EC, Shaw-Hawkins S, Willeit J, Liu C, Zhu J, Tucker AT, Xu Q, Caulfield MJ, Ye S: ADAMTS7 Cleavage and Vascular Smooth Muscle Cell Migration Is Affected by a Coronary-Artery-Disease-Associated Variant. Am J Hum Genet 2013;92:366-374.

25 Maouche S, Schunkert H: Strategies beyond genome-wide association studies for atherosclerosis. Arterioscler Thromb Vasc Biol 2012;32:170-181.

26 Du Y, Gao C, Liu Z, Wang L, Liu B, He F, Zhang T, Wang Y, Wang X, Xu M, Luo GZ, Zhu Y, Xu Q, Wang X, Kong W: Upregulation of a disintegrin and metalloproteinase with thrombospondin motifs-7 by miR-29 repression mediates vascular smooth muscle calcification. Arterioscler Thromb Vasc Biol 2012;32:2580-2588. 